\title{
CONCEPTUAL RESEARCH ON THE TERM FACILITATION: REDUCING AN ELEPHANT TO CHEWABLE CHUNKS
}

\section{Rinie Schenck, Huma Louw}

\section{INTRODUCTION}

The term "facilitation" is often used in promoting social change and used by change agents to refer to many actions they perform to bring about learning, change and development. For instance, in training and education the terms used are "facilitators" and "learners" and in other contexts facilitation is more comprehensive than merely facilitating learning. It may include different types of change and development. Soal (2004:55) refers to the latter form of facilitation as "facilitation through the change threshold".

Often change agents refer to their actions as facilitation, but do not clearly describe the meaning of the concept, or they act in such a way that it cannot be regarded as facilitation but rather as instruction, induction or top-down methods.

The need for this article arose because of this lack of clarity and the different meanings that are attached to the concept of facilitation and its theoretical base.

\section{AIM OF THE ARTICLE}

With this article the researchers used a conceptual research process to:

- explore the meanings of the concept of facilitation;

- identify the key facilitating actions/behaviours of the facilitator and the potential/purpose of these actions;

- provide a theoretical base explaining and understanding facilitation.

\section{THE CONCEPTUAL RESEARCH PROCESS}

According to Leuzinger-Bohleber (2007), conceptual research is not research by concepts but on concepts. To explore the meanings, theory and actions of the concept facilitation, we undertook a conceptual research process as described by Friedl, De Vos and Fouché (2002:435),who suggest that the field of conceptual research represents, to a certain degree, unchartered ground and they express the hope that more authors will elaborate on the research methodology. As the authors of this article, we are aware of the risk of moving into this unchartered territory, but hope that, in doing so, we can add to knowledge on conceptual research.

Friedl et al. (2002) propose the three stages of conceptual research as extraction, definition and analysis.

- Extraction is the observation of the use of a concept to determine its functioning within its context. Extraction can include the identification of the concept the researcher wanted to research, formulation of a question about the concept, literature review and data collection.

Extraction in this research was from facilitation guides by different authors. We highlighted how these authors formulated the activities for the facilitators and participants. What words are used to create the context and engage the participants in action, learning, change and development? What skills are required for facilitation? What do they hope to achieve with these activities? What are the intended purposes of the activities? 
- Definition takes place after the concept has been closely observed, using a selection of the research methods. According to Friedl et al. (2002:442), definition aims at answering the research questions.

Description of the concept (definition) was based on the extraction from literature on the meaning/s given to the concept of facilitation by different authors.

- Analysis includes the formulation of general principles linked to the concept and is aimed at making the results useful for application and further scientific discussion.

In the analysis stage the concept of facilitation will be linked to theoretical principles and made "available for practical application" (Friedl et al., 2002:442).

\section{STAGE 1: EXTRACTION}

\section{EXTRACTION OF THE TECHNIQUES AND ACTIVITIES FOR FACILITATION}

According to Friedl et al. (2002:442), extraction means the observation of the use of the concept to determine its functioning within its context.

An extraction was done on guidelines and handbooks for facilitators, e.g. Hope and Timmel (1997), Pretty, Gujit, Thompson and Scoones (1995), Pitt and Michel (1992), Chambers (2002), Muir (www.guilamuir.com, 2006), Soal (2004) and Selener, Endara and Carvajal (1999).

The researchers extracted the suggestions in the proposed activities in the guidelines and handbooks and attempted to identify the intended purpose of the suggestions in the table below.

TABLE 1

EXTRACTION OF INSTRUCTIONS OF FACILITATION ACTIVITIES AND THEIR INTENDED PURPOSES

\begin{tabular}{|c|c|}
\hline Suggested activities used & Intended purpose of the activities \\
\hline $\begin{array}{l}\text { 1 } \\
\text { "Engage participants in..." } \\
\text { "In groups, in pairs share... " } \\
\text { "Share..." } \\
\text { "Together do/make..." } \\
\text { "Tell each other..." }\end{array}$ & $\begin{array}{l}\qquad 1 \\
\text { - To create a growth environment } \\
\text { - To encourage participation } \\
\text { - To encourage free talk } \\
\text { - To get to know each other } \\
\text { - To build relationships } \\
\text { - To create equality between facilitator and participants } \\
\text { - To recognise strengths and abilities } \\
\text { - To learn from one another }\end{array}$ \\
\hline $\begin{array}{l}\text { "Listen to..." } \\
\text { "Discuss..." } \\
\text { "Debate..." } \\
\text { "Share..." }\end{array}$ & $\begin{array}{l}\text { - } 2 \\
\text { - To encourage communication } \\
\text { - To make the voices of the participants heard } \\
\text { - To formulate } \\
\text { - To listen } \\
\text { - To conceptualise }\end{array}$ \\
\hline $\begin{array}{l}3 \\
\text { "Please tell more..." } \\
\text { "How did you discover this?" } \\
\text { "Where did you learn this from?" }\end{array}$ & $\begin{array}{l}\text { C } \\
\text { - To recognise existing knowledge } \\
\text { - To appreciate knowledge and skills by facilitator, from }\end{array}$ \\
\hline
\end{tabular}




\begin{tabular}{|c|c|}
\hline Suggested activities used & Intended purpose of the activities \\
\hline "Who will learn from it?" & one another and self \\
\hline $\begin{array}{l}\text { "Draw..." } \\
\text { "Create a collage..." } \\
\text { "Role play..." } \\
\text { "Write..." } \\
\text { "Using your own words/ } \\
\text { language/idioms..." } \\
\text { "Sort the cards..." } \\
\text { "Build..." } \\
\text { "Play..." } \\
\text { "Dramatise..." }\end{array}$ & $\begin{array}{l}\text { - To give voice to and critically think through creative } \\
\text { activities } \\
\text { - To discover and learn experientially } \\
\text { - To conceptualise } \\
\text { - To make it relevant }\end{array}$ \\
\hline $\begin{array}{l}5 \\
\text { "Brainstorm..." } \\
\text { "Generate ideas, solutions, } \\
\text { answers" "Explain..." } \\
\text { "Prioritise..." } \\
\text { "Reflect..." } \\
\text { "Evaluate..." } \\
\text { "Debate..." } \\
\text { "Discuss..." } \\
\text { "Read the case study... and ..." }\end{array}$ & $\begin{array}{l}5 \\
\text { - To think creatively and critically based on their own } \\
\text { knowledge }\end{array}$ \\
\hline \begin{tabular}{l}
\multicolumn{1}{c}{6} \\
Structured techniques and \\
activities like: \\
SWOT analysis \\
Venn diagram \\
community walk/drawing \\
transect walk \\
nominal group techniques \\
force field analysis \\
matrix rankings \\
river of life \\
simulation games
\end{tabular} & $\begin{array}{l}6 \\
\text { - To encourage critical thinking, reflection on their own } \\
\text { situation, giving of new meaning } \\
\text { - To simulate experiences of possible realties }\end{array}$ \\
\hline
\end{tabular}

\section{STAGE 2: DEFINITION OR DESCRIPTION OF THE CONCEPT (meaning/s given to the concept of facilitation)}

To add to the extracting from the above literature, we also looked at the description of two different dictionaries.

The Concise Oxford Dictionary (1990:419) describes facilitation as "a skill that is used to make easy or less difficult and more easily achieved" and Bartlett' Roget's Thesaurus (1996) includes concepts like finding/making meaning, making comprehensible, setting free, making easy and possible, making simple, accessible and relevant. 
From the extraction in Table 1 the intended purposes of the different activities were explained as e.g. creating growth, encourage participation, encourage critical thinking learn, make easy, appreciate, discover, create opportunities, making voices heard, build relationships/networks, getting to know.

The facilitator uses all these activities during the process of facilitation to make the learning, development and growth processes possible, accessible and relevant for the participants by engaging them in an interactive participatory process.

The opposite of facilitate would be not to look for and find alternative ways, but to persist in one way to instruct, in writing or otherwise, without making understandable or relevant through dialogue and discussion. The opposite of facilitation then is to hinder, complicate and discourage; to instruct, or to tell, how, when and where things should take place.

This understanding of facilitation implies that when endeavouring to facilitate processes, we need to constantly ask ourselves whether we are making it easier and relevant for people to change, develop and learn through the process. We need to break the large whole down into parts and present them bit by bit or in "absorbable" pieces in a way that fits with the participants' existing knowledge.

Facilitation is therefore seen as the opposite of top-down, verbal or visually attractive presentations, where the audience members are passive recipients of information and instructions, but do not participate in the process. It is seen as a process in which participants should be actively involved and at the very least be allowed to "mull over the information" to process it mentally, to make it their own for self-growth and self-development. The end result should be the development of the self. This is more than providing knowledge, teaching skills or increasing access to resources. It is an internal transformation or development process through which self-worth increases (Nturibi, 1984; Rahman, 1993).

According to Soal (2004:55), the spectrum of facilitation is extremely broad and can range from creating a space in which everybody can have their say, to facilitating processes where people can "face and take on board the unknown, through letting go of old knowledge, habits or ways of seeing ... to step over existing boundaries, entering and transcending the threshold of change”.

\section{STAGE 3: ANALYSIS AND BUILDING THEORY AND APPLICATION}

During the analysis stage of the research the aim is to illustrate its practical application and link the concept to the theory.

From the extraction the following intentions of the activities were deduced:

\section{Intended purposes of facilitation}

\section{Intended purpose 1: Creating a context for learning, development and change}

Rogers (1969:158) states that human beings have the natural potential to learn and change, and that this potential can be released under suitable conditions. Facilitation starts by creating a warm, congruent, accepting and understanding context in which people can grow, risk, learn, make mistakes and change in ways that are consistent with their self-structure. There should be no threat to the participants. The participants should be accepted and respected by the facilitator. Within this safe context they will take the risk to learn and grow from the inside out. 


\section{Intended purpose 2: Listening and learning from each other and self}

People are encouraged in different ways to speak rather than be spoken to, so that their voices and opinions are heard and acknowledged. Freire (1972) refers to this process as breaking the "culture of silence". Slim and Thompson (1993) see "speaking out" as an act of power.

Sharing brings a richness of ideas and material to learn from. It is more about listening than being listened to. Informal seating in circles instead of rows can encourage communication, interaction and participation. This allows people to speak, open up new fields and reveal hidden voices and hidden spheres of experience, thereby enabling them to share social, cultural and economic activities and practices - in short, to share their stories and experiences as part of learning from the known to the unknown.

The purpose is to listen to participants' needs, perceptions, knowledge, skills and values. Their own unique culturally relevant way of learning, development and change is important.

\section{Intended purpose 3: Appreciative enquiry focusing on the strengths}

Appreciative enquiry seeks to identify whatever is positive. This means that the facilitator has respect for, and an appreciation of, the knowledge and skills of the participants/community/clients. The facilitator probes, with appreciation, for the knowledge and skills of the people that will be used as a basis for their further learning/development. Rogers (1969:158) believes that significant learning, growth and development take place when the person experiences the subject matter or processes as relevant for his or her own purposes.

\section{Intended purpose 4: Encouraging critical thinking}

Critical thinking and giving a voice to the participants implies that facilitators use creative activities to enhance critical thinking and reflection on their own situation (compare Freire, 1998). This enables the participants to express their own thinking, concerns and ideas.

According to Rahman (1993:195), as people are encouraged to think critically and become free to enquire, they are also able to better take charge of their own lives, plan and take action, and release their creative potential. Creativity blossoms in an atmosphere of freedom (Rogers, 1969:163). Oakley (1982:260) quotes a community member as saying:

An outsider who comes with ready-made solutions and advice is worse than useless. He must first hear from us what our questions are, and help us to articulate the questions better and then help us to find solutions. Outsiders also have to change. He alone is a friend who helps us to think about our problems on our own.

\section{Intended purpose 6: Learn, change, develop by doing}

Rogers (1969:162) is of the opinion that significant learning and development occur through doing. Placing the person in direct experiential confrontation with practical, ethical and philosophical problems and personal issues is one of the most effective modes of promoting learning, change and development. This way of working promotes participation and enables participants to choose their own directions, discover their own resources, decide on their own actions and live the consequences of their actions. Learning by doing also includes the whole person, feelings, experiences, perceptions and intellect.

\section{Intended purpose 7: Creating/constructing new meanings}

This involves activities that encourage people to create new and more relevant meanings for themselves. This constitutes the change process. It restores human dignity, self-worth, 
confidence, pride, a belief in oneself, initiative, creativity through acceptance, participation and taking control.

\section{Features of the facilitation process}

With these purposes in mind, facilitation has the following features:

\section{Feature 1: A people-centred process}

The focus is on creating space for participants to learn, develop and change, and also on people's needs and relevant change processes.

\section{Feature 2: An unpredictable, unique process}

The end result is unpredictable. Each person will gain differently from the process and the facilitators cannot predict or prescribe what and how the participants should learn, change and develop.

\section{Feature 3: A dialogical, multidirectional process}

Facilitation takes place through dialogue, sharing, learning, reflecting and co-evolving ideas and decisions.

\section{Feature 4: An experiential, incremental and evolutionary process}

We learn by doing and participating. We learn based on our own knowledge, skills and experiences. Learning and development move from the familiar to the unfamiliar. Learning, development and change come from learning from mistakes and embracing errors (Korten \& Klaus, 1984).

\section{Feature 5: An inclusive, participatory and democratic process}

Participation implies that people share fully and have an equal voice in any efforts directed towards change. We have entered the postmodern era where differences and pluralism are appreciated equally. We focus on inclusivity rather than exclusivity. It is the variety of differences between viewpoints that make them a rich resource. To work inclusively is complex and requires maturity and self-knowledge from the facilitator. Sometimes it is easier to exclude certain people than include those who see things differently.

\section{Feature 6: An indigenous, local and relevant process}

The process will be appropriate and relevant to the participants if it is based on their needs, culture and values. Indigenous communication channels can be used to process information, e.g. via idioms, stories, songs and dance (compare Louw \& Schenck, 2002).

\section{Feature 7: A needs-based process}

Facilitation is based on the needs of the participants, what is important and relevant to them, and what they feel strongly about.

\section{Feature 8: A problem-posing process}

Based on the ideas of Freire $(1972,1998)$, the authors of this article facilitate change through a problem-posing process. Facilitation means encouraging and making it possible for people to search for their own answers to problems. This is built on the assumption that people can think for themselves, are creative and are able to act to change situations (Hope \& Timmel, 1997).

\section{The actions of the facilitator}

To be able to fulfil the intended purposes of facilitation, the facilitator can act in the following ways: 
- Set the initial mood or climate based on trust in the participants;

- Value participants through respect, individualisation, self-determination and confidentiality;

- Elicit and clarify the purposes of the individuals and the group;

- Work from the participants' reality and frame of reference;

- Belief in the participants' potential to find their own answers, by not providing answers but posing critical questions/reflection;

- Attend and listen to and empathise with the participants;

- Encourage and create opportunities for participants to exercise self-determination, selfevaluation, critical thought, risk-taking and decision-making;

- Create opportunities for participation, e.g. discussions, simulation games, working in small groups;

- Enable and encourage participants to fully contribute their ideas;

- Acknowledge and appreciate contributions;

- Make available the widest possible range of resources for learning, change and development (Rogers, 1969:164);

- Focus equally on process and content;

- Present directions for exercises clearly and enthusiastically;

- Reflect critically on their own values, attitudes and stereotypes;

- Have fun and build healthy relationships continuously;

- Guide without imposing or steering too much;

- Share information and knowledge;

- Encourage sharing and learning;

- Provide opportunities for the participants to discover things themselves. Don't feel compelled to explain everything. Act as a facilitator to their process;

- Make himself or herself as a facilitator available as a flexible resource to be utilised by the participants he or she interacts with (Rogers, 1969:165);

- Make it fun. Humour and creativity come from, and create, the same chemicals in the brain, says Guila Muir (www.guilamuir.com). People are much more open to learning when they are having a good time and when they are actively involved;

- Turn telling into questions that can lead to self-discovery.

Facilitation does not include the following actions, which create an UNSAFE environment:

- Interrupting;

- Being impatient;

- Completing participants' sentences for them;

- Attacking those who disagree;

- Sending negative non-verbal messages;

- Lecturing;

- Deciding for participants;

- Doing for participants; 
- Talking on behalf of participants;

- Educating;

- Informing;

- Being critical;

- Telling people what to do;

- Excluding people for various reasons.

Techniques/actions are available for use in facilitation, but they must be used with discernment; if not, they may be more harmful than useful. Shriver (1995) formulated valuable criteria based on people-centred principles to be used in the selection of facilitation techniques:

- Does this technique respect/enhance the dignity of people?

- Does it show respect, understanding?

- Does it create trust?

- Does the technique enhance appreciation and understanding of diversity (gender, race, sexual orientation, culture, individual)?

- Does it bring out and allow different voices?

- Does it enhance growth and development?

Each technique should be "measured" against these criteria in any unique context. The technique might meet certain criteria when working with children, but not necessarily with adults. It might be valuable in one community, but not in the next. It may offend the values of the participants or the perception they have of themselves. Techniques should be used sensitively for a particular group of people and in a particular context.

Basically, facilitation techniques will aid facilitators to communicate with participants more effectively to be able to guide them through learning and change processes.

\section{The thinking (theory) of the facilitator}

If the focus of facilitation is on the self-development of the individual, groups and community, it requires a people-centred way of thinking that values people and places them at the centre of the process. According to people-centred thinkers in therapy, education and (community) development such as Carl Rogers (1986), Paolo Freire (1972, 1998), Robert Chambers (1983, 1997), Anisur Rahman (1993) and David Korten (in Korten \& Klaus, 1984), the following are some of the assumptions about people that are important when facilitating change, growth, learning and development:

- People have knowledge and skills and they are experts of their own lives and worlds. We have to believe in people's potential and trust them to take responsibility for their own growth. The facilitator is not the only expert. As facilitators, we do not have to impose, but we have to know how to access and release people's knowledge and skills.

- People are complex and diverse and have their own realities from which we can learn and tap into, and on which they base their own learning. (We need to see them as unique people with unique change processes.) The learning, development or change processes will therefore be different for each unit (individual, family, group or community). 
- The facilitation process takes place through the relationship. According to Taylor (2001:24), the relationship is at the heart of facilitation itself. The nature and quality of the relationship will have a major effect on the quality of the facilitation process.

Le Roux (2005:95) refers to Tenenbaum, who states that "learning occurs through the establishment of malleable mental constructs. Learning is therefore enhanced through the creation of environment that promotes the continual adaptation of the learner's mental schemata to the external environment". This environment consists of acceptance and respect of the self and others, warmth, congruence and trust within a horizontal, equal relationship and essential for the facilitation of any change as in social work. Taylor (2001:25) further says that "an inescapable reality is the fact that forming and maintaining trusting relationships not only takes time but also takes quality time". No professional can therefore rush into the life of a person, a group, family or community and try to facilitate change. We need to spend time in order for them to trust us. We never stop building relationships with people.

\section{The facilitator}

It also seems that the person of the facilitator is of great importance. The facilitator is not detached from the process. Pretty et al. (1995:8) state that good facilitators:

- have a warm personality, with an ability to show approval and acceptance;

- have social skills and an ability to relate well with the group;

- generate ideas with, and use the skills of, the participants;

- are skilled in noticing the processes within the group;

- have enthusiasm for the subject;

- are flexible in responding to participants' changing needs;

- have knowledge of the subject matter.

Taylor (2001:24) lists the following qualities and abilities required by facilitators in order to establish a "developmental relationship" with the participants:

- An in-depth knowledge of themselves, and the agency they represent, including the power they have and their own needs that they will be meeting through the relationship;

- Sensitivity to how they are perceived and experienced by the participants and what they represent to them (hope, congruency, trust);

- The ability to articulate clearly and honestly who they are, their purpose and intentions (congruency);

- The ability to listen consciously, deeply, actively and with empathy in order to appreciate the purpose and intentions of others (empathy);

- The ability to build trust through being worthy of trust in all that they do and undertake to do; Freire (1972:41) regards trust as the most critical aspect in the relationship: "They (helpers) talk about people but they do not trust them; and trusting people is the indispensable precondition ... A real humanist can be identified by his trust in people";

- The ability to negotiate agreements (contracts) that honestly reflect the interests of all parties and encourage co-ownership (trust);

- The ability to allow and encourage their relationships to change over time. 


\section{CONCLUSION}

This article devoted attention to the conceptual research process with the aim of developing clarity about the concept of facilitation. Hopefully this research will contribute to the body of knowledge of conceptual research and add to the clarification of the concept of facilitation to the extent that its applicability is clearer in the process of facilitating learning, development and change in communities, groups and individuals. The principles are the same, no matter the context.

In summary, facilitators are the co-learners and co-communicators in the journey of participants' discovering their own voice and abilities. According to Freire (1998), facilitation has the potential to bring about transformation which sets free. It can introduce change in different ways and at different levels of people's existence.

\section{REFERENCES}

BAWDEN, R. 1994. Creating learning systems: a metaphor for institutional reform for development. In: SCOONES, I. \& THOMPSON, J. Beyond farmer first. London: ITP.

CHAMBERS, R. 1983. Rural development: putting the last first. London: ITP.

CHAMBERS, R. 1997. Whose reality counts? Putting the first last. London: ITP.

CHAMBERS, R. 2002. Participatory workshops: a sourcebook of 21 sets of ideas and activities. London: Earthscan.

FREIRE P. 1972. Pedagogy of the oppressed. Harmondsworth: Penguin.

FREIRE. P. 1994. Paolo Freire on higher education. New York: Albany State University.

FREIRE P. 1998. Pedagogy of freedom: ethics, democracy and civic courage. Lanham: Rowman and Littlefield.

FRIEDL, J.J., DE VOS, A.S. \& FOUCHÉ, C.B. 2002. Conceptual research. In: DE VOS, A.S., STRYDOM, H., FOUCHÉ, C.B. \& DELPORT, C.S.L. Research at grassroots: for the social sciences and human service professions. Pretoria: Van Schaik.

GROBLER, H.D., SCHENCK, C.J. \& DU TOIT, A.S. 2003. Person-centred communication: theory and practice. Cape Town: Oxford.

HENDERSON, P. \& THOMAS, D.N. 1989. Skills in neighbourhood work. London: Allen \& Unwin.

HOPE, A. \& TIMMEL, S. 1997. Training for transformation books 1, 2, 3. Johannesburg: Westro.

KORTEN, D. \& KLAUS, R. 1984. People-centred development. West Harford: Kumarian.

LE ROUX, C. 2005. Can indigenous knowledge systems (IKS) come to the rescue of distance adult learning facilitation? South African Journal of Higher Education, 18(3):92-105.

LEUZINGER-BOHLEBER, M. 2007. What does conceptual research have to offer? Available: http://www.pep-web.org/document.php?id=ijp.085.1477a.

LOUW, H. 2002. Community work. Study Guide for SCK303-9. Pretoria: Unisa.

LOUW, H. \& SCHENCK, C.J. 2002. Learning through rediscovery and reclaiming local/indigenous knowledge and skills. Africanus, 32(2):93-108.

NTURIBI, D.N. 1984. Working with communities. Nairobi: Unicef. 
OAKLEY, P. 1982. Continuing enquiry into participation in development in the Third World. Community Development Journal, 17(3):259-262.

PITT, B. \& MICHEL, M. 1992. Making workshops work. Cape Town: ERIP.

PRETTY, J., GUJIT, I., THOMPSON, J. \& SCOONES, I. 1995. Participatory learning and action: a trainer's guide. London: IIED.

RAHMAN, A. 1993. People's self development: perspectives on participatory action research. London: Zed.

ROGERS, C.R. 1969. Freedom to learn. London: Constable.

ROGERS, C.R. 1986. Carl Rogers on personal power. London: Constable.

SCHENCK, C.J. \& LOUW, H. 1995. A people-centred perspective on people-centred community development. Journal of Social Development in Africa, 10(2):81:92.

SCHRIVER, J.M. 1995. Human behaviour and the social environment: Shifting paradigms in essential knowledge for social work practice. Boston: Allyn and Bacon.

SELENER, D., ENDARA, N. \& CARVAJAL, J. 1999. Participatory rural appraisal and planning workbook. Ecuador: International Institute of Rural Construction.

SLIM, H. \& THOMPSON, P.R. 1993. Listening for a change: oral testimony and development. London: Panos.

SOAL, S. 2004. Holding infinity, guiding social processes: a workbook for development practitioners. Cape Town: CDRA.

TAYLOR, J. 2001. Establishing developmental relationships. Available: www.cdra.org.za.

TAYLOR, J., MARAIS, D. \& KAPLAN, A. 1997. Action learning for development: use your experience to improve your effectiveness. Cape Town: Juta.

TAYLOR, J., MARAIS, D. \& HEYNS, S. 1998. Community participation and financial sustainability: action-learning series. Case studies and lessons from development practice. Cape Town: Juta.

TUCKMAN, B. 1965. Developmental sequence in small groups. Psychological Bulletin, 63:384-399.

TUCKMAN, B. \& JENSEN, M. 1977. Stages of small group development. Group and Organizational Studies, 2:419-427.

\section{ANNUAL REPORTS}

Emergence - From the inside out. Annual report 2003/2004. Cape Town: CDRA.

Measuring development - Holding infinity. Annual report 2000/2001. Cape Town: CDRA.

\section{INTERNET WEBSITES}

www.nasaga.org

http://wwwgmu.edu/student/csl/5stages.html

http://wateroutreach.uwex.edu.education/role.cfm

http://ohiowatersheds.osu.edu/owa/lessons/4html

http://www.bsu.edu/soa/resources/facilitation/ 
380

http://www.guilamuir.com

http://ctb.ukans.edu/tools/EN/chapter_1016.htm

http://www.nea.gov/resources/Lessons/ DUNCAN1.HTML

http://www.nea.gov/resources/Lessons/ DUNCAN2.HTML

http://www.nsdc.org/library/publications/tools/tools9-97rich.cfm

\section{DICTIONARIES}

CONCISE OXFORD DICTIONARY ( $8^{\text {th }}$ ed). 1995. s.v. “facilitation”. 1990.

BARTLETT'S ROGET'S THESAURUS. 1996. s.v. “facilitation”. Little, Brown and Company.

Prof Rinie Schenck and Dr Huma Louw, Department of Social Work, University of South Africa, Pretoria, South Africa. 